\title{
From a modern power plant to a factory of culture
}

\author{
Meanings and values at the Hanasaari A power plant as an object of \\ industrial heritage in Helsinki 1957-2007
}

MAIJA KÄRKI*

\begin{abstract}
The Hanasaari A power plant in Helsinki in Finland has gone through several fundamental changes during its life cycle. It was constructed at the turn of the 1960s to produce energy in a modern, efficient manner and delivered both electricity and heat to Helsinki for several decades.

After being converted to a reserve power plant in the beginning of the 21 st centu$r y$, it served as a "cultural factory" where music videos and television series were shot. After the 2007 decision to demolish the power plant, Helsinki Energy launched a documentation project aimed at preserving the history and industrial heritage of the power plant. This article describes the multi-faceted life cycle of Hanasaari $A$ and examines the underlying values and meanings associated with its industrial heritage.
\end{abstract}

Key words: Industrial heritage, power plants, city planning, oral history, Hanasaari A power plant, Helsinki Energy.

In this article I examine the past and present values and meanings associated with the $\mathrm{Ha}$ nasaari A [Hanaholmen in Swedish] power plant in Helsinki [Helsingfors in Swedish]. The focus is the fundamental changes that the power plant has gone through in its life cycle. The purpose is not to deal with the actual workings of the power plant itself, nor to pursue full objectivity. Instead, my objective is to document the life cycle of the power plant from the perspective of the workers. I documented this industrial heritage by conducting interviews during the summer of 2007 and because I became close to the community associated with Hanasaari A, the perspective of this article is moderately subjective.

The article examines the many phases of the Hanasaari A plant, beginning from its construction stage in the early 1960 s to the decades of its intensive use and its final phase as a standby power plant and its use in conjunction with cultural production. These changes reflect deeper social changes in Finland, which I attempt to reveal to the reader. I 


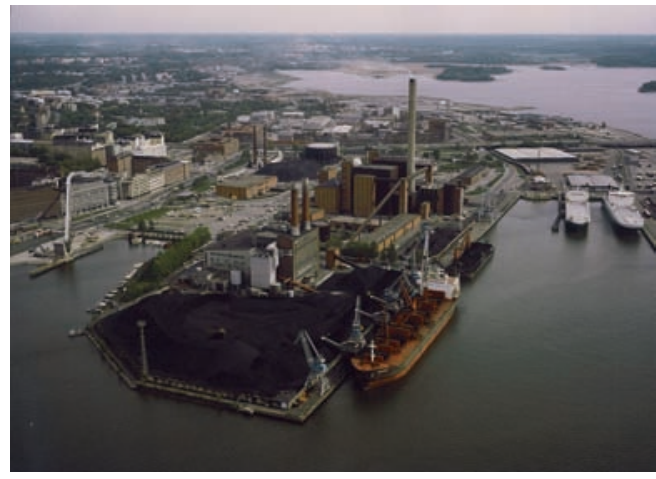

Fig. 1. The energy maintenance area of Helsinki Energy is a unique example of industrial construction, with features that date from approximately an entire century. This aerial photograph shows the maintenance area of Sörnäinen. In the background is the old Suvilahti power plant, in the middle the Hanasaari B power plant and in the foreground the phased-out Hanasaari A power plant. The architecture of the each power plant reflects the values and ideals of the time at which they were designed and built. Suvilahti reflects the ideals of modern technology and new reinforced-concrete construction at the turn of the 20th century. Hanasaari A echoes the emphasis on financial considerations and efficiency in the period after the wars. Hanasaari B mirrors the growing conscience about environmental and cityscape factors in the 1970s (Aalto 2006: 29). Photograph from the archives of Helsinki Energy.

specifically examine the public discussion of the power plant's future and the intense documentation work in the community after the decision to demolish the power plant.

Hanasaari A has stirred many emotions and discussions throughout its history as it is a large industrial plant located in near the centre of Helsinki. In this article, I attempt to open this discussion and provide a voice for the workers at the Hanasaari A power plant, to express their values, opinions and visions. There are a lot of quotations - because I wanted them to address the reader directly.

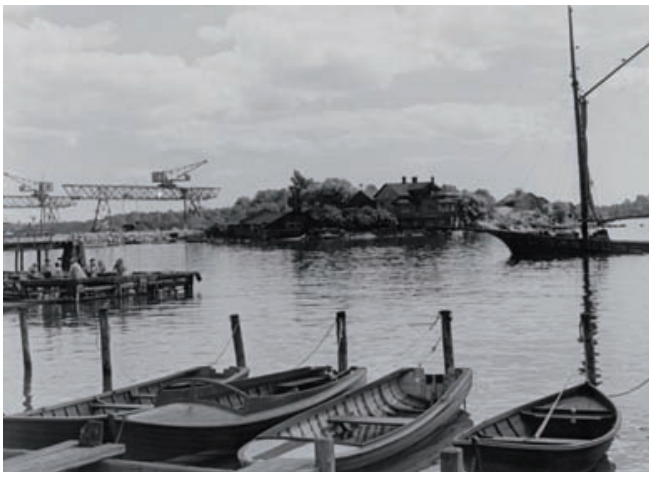

Fig. 2. Hanasaari in the 1950s, before the power plants were constructed. Photograph from the archives of $\mathrm{Hel}$ sinki Energy.

\section{HANASAARI A AS A POWER PLANT}

"A summer-time stroller who happened to walk the promenade of Sörnäinen [Sörnäs in Swedish] in the early 1950s and look upon the island of Mustikkamaa [Blåbärslandet in Swedish] bathing in sunlight, might see a small, rocky island with an old house surrounded by trees in the centre, at the back a group of domestic buildings and on the foreshore a tiny dock surrounded by boats. Our stroller could never foresee that this still-idyllic island ... was doomed to be left behind in development and to become a scene for grand humane, material and financial efforts." (Toivainen 1967: 7). So poetically spoke Eino Toivainen MSc, the director of Helsinki city's power plant new building department, in the inauguration celebration for Hanasaari A on 26.4.1967.

A municipal institution Helsinki Energy, formerly known as Helsinki City's power plant was founded in 1909 (cf. Turpeinen 1984). The first steam power plant, Suvilahti [Södervik in Swedish], was located in the eastern central city area, Sörnäinen. Later three power 
plants were situated in the area of Sörnäinen and the most recent power plant Hanasaari B, which was founded in 1974, is still in use (Fig.1.) The city developed rapidly in 1950 s and the energy requirements grew extensively. After the founding of Salmisaari [Sundholmen in Swedish] power plant, an area was reserved from Hanasaari area for a new power plant in 1956 to meet the city's growing needs for more electricity (Aalto 2006: 9, 15, 18).

Retired older machine mechanic, who worked in Hanasaari A, reminisced about the $\mathrm{Ha}$ nasaari area before the construction of the power plant. "My father made a boat long before that [Hanasaari A was built], sometimes in the beginning of the 1950s. I was like a little boy, I was there with him. We always came through the gasworks, I remember there was a little shiny bridge, below which there were, like huge yellow gas bubbles. I thought if you fall there it's a sure death, methane probably smelled like that." (TYKL/spa/519: informant 45) (Fig. 2).

Construction work on Hanasaari A began in haste in the spring of 1957 . The main responsibility for the construction plans lay with the Helsinki City's power plant new building department's planning department, where the director was Vilho Immonen. Architect Vera Rosendahl was in charge of the design of the power plant. Hanasaari was also a training project for young engineers, because other new power plants were needed. (Aalto 2006: 18-19)

Hanasaari A was designed and constructed to meet efficiency requirements, while the overall environment and the power plant's integration into the cityscape were not considered. The shore of Sörnäinen was during the 1960s clearly an industrial area, while the Merihaka residential area (Havshagen in Swe-

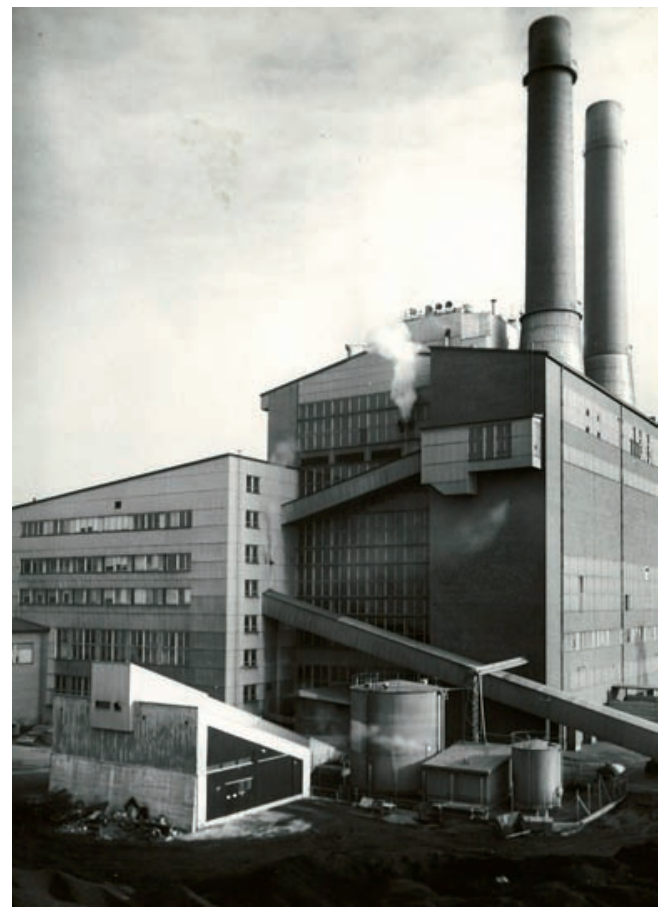

Fig. 3. Hanasaari A power plant, which was modern at the time it was constructed and represented the newest techniques. Compared to the flat Suvilahti power plant, Hanasaari $A$ is different in its constructional bulks. The steam boilers were large and particularly high, making it necessary to extend the building upwards. The window spaces are huge in order to maximize the availability of natural light.

Hanasaari A was constructed from two parts. The boiler hall with its ribbon-shaped window lines and the façade with brick panelling provided the seawards-facing vista. The lower part, facing the city, was the turbine hall. This was panelled with grey fibre-cement sheets and the façade was dominated by a grand window covering (Aalto 2006: 36). Photograph from the archives of $\mathrm{Hel}$ sinki Energy.

dish) was not yet built. Vilho Immonen's efficiency principles rolled over all architectonical views (Aalto 2006: 36, Osmo Arponen's main speech in the 30th anniversary of Hanasaari B 11.6.2004). Hanasaari A became a functional power plant and former workers remembered that it was too cramped and unpractical as a consequence of an effort to design it to be as 


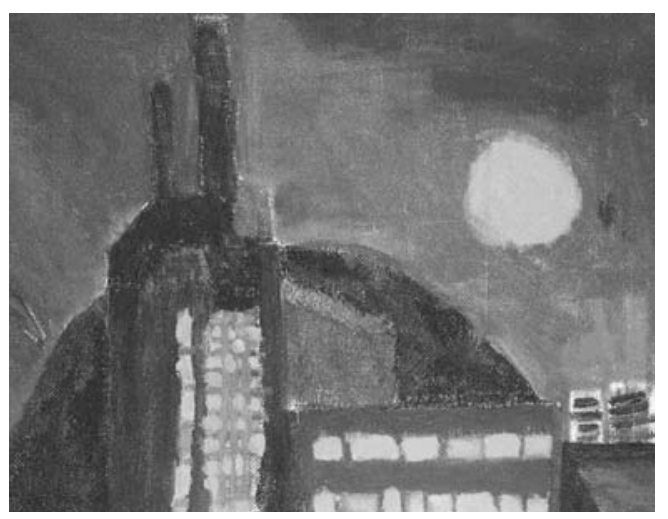

Fig. 4. A drawing done by a child of one of the Hanasaari A power plant's workers, showing the plant at night In the background are the black coal warehouse and the buildings of Meribaka. The drawing clearly shows the power plant's two sections, with the large window panelling. Workers' children were frequently allowed to visit the power plant, and family days were organized (e.g. TYKL/spa/519: informants 1, 4, 20, 43).

efficient as possible (e.g. TYKL/spa/519: informants 4, 19, 23, 41) (Fig. 3). Hanasaari A was officially inaugurated on 26.4.1967 (Aalto 2006: 20).

The equipment for Hanasaari A came mainly from Germany, so the German technicians were a common sight to Finnish workers. Several technical innovations were used in Hanasaari and it truly represented the newest power plant techniques in the beginning of 1960s (Arponen 2004). The 1960s is considered to be the pioneering period of the power plant. Engineers in the 1950s and 1960s had mostly worked at sea, because the qualifications and skills needed could only be acquired by working in ships. Typical for Hanasaari $A$ is also that it was often a workplace for several generations. Many workers therefore share a deep relationship with the power plant (e.g. TYKL/spa/519: informants 43, 44, 47) (Fig.
4.) During their working years, they also acquired in-depth knowledge about how to use the power plant and its features.

Decades later, in the late years of Hanasaari A's utilization as a power plant, the technology was already out of date. "Because it was an old power plant, you had to wrench valves ... It took just that knowledge and because it was so much pure handicraft, each shift had its own unique way to do things like starting up the power plant - what do they did in each phase and how, what kind of fires they used to start ... You had to know lots of little things here and there, you knew that some magnetic valve didn't move if you went there to knock it, that sort of brilliant things. And of course people were a little bit ..., they don't tell always everything, they wanted to keep this sort of knowledge to themselves." (TYKL/spa/519: informant 43). These kinds of hands-on skills were the source of power plant workers' professional pride. The knowledge that in their hands was the heat and electricity supply of Helsinki and the knowledge about the individual features of the plant made for a closeknit, united working community. Responsibility for operating the plant led to immense amounts of overtime for many workers throughout the 1960s (e.g. TYKL/spa/519: informants 39, 44) (Fig. 5.).

In the early years of Hanasaari A, the area was very open. The course of life was at times even wild; workers tell stories about escaping customs officers by running onto a coal field with bottles of spirits that that they'd bought from Polish coal ships, holding card-playing circles that lasted for days, selling cars to Russians and loading them on to the Russian ships by night (e.g. TYKL/spa/519: informants 43, 47). Such situations were described as late as in 1981 in an article by Helsinki 


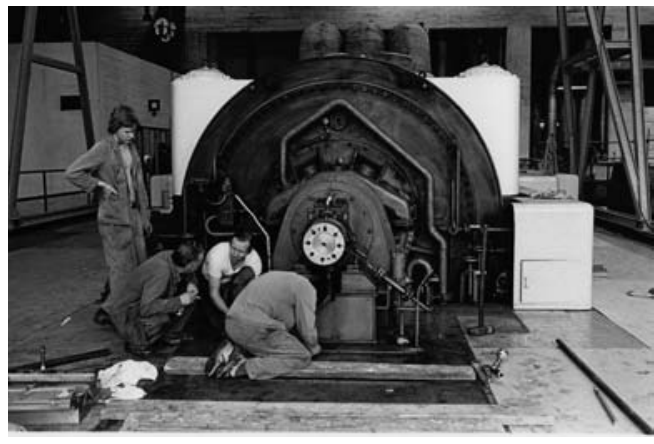

Fig. 5. Turbine inspection in 1977. Annual maintenance took place during the summer, when the demand for electricity in Helsinki was smaller. This period was extremely busy and the maintenance workers made plenty of over-time (e.g. TYKL/spal519: informants 39, 44). Photograph from the archives of Helsinki Energy.

Energy's paper Sähkösanoma with a headline like "Harbour and Traffic - the Nuisances of Hanasaari". The article recounts that the power plant area was kept as open as possible in order to minimise vandalism. Lively traffic of coal, oil and ash and the influence of the harbour were still visible in the area in the 1980s.

Hanasaari A was a cramped place and this possibly partly caused noise problems and the laboratory received complaints from residents living nearby. Due to these alleged dust problems, the laboratory carried out measurements of the noise and dust fallouts (TYKL/ spa/519: informant 34, Terveysviraston valvontaosasto ...1989: 20-21). An emerging sense of responsibility about the environment, along with media attention during the 1980s, affected the overall reputation of Hanasaari A as well as the atmosphere within the workers' community. "Then that thing, which did affect the atmosphere, if you remember, when there came a lot about effluents, there were always those two, those pipe ends. At one point it felt really bad when someone asked where you work and you had to answer there, in 'Hanasaari'. Then in the 1970s they needed to get heat and electricity at all costs, that was the first thing, then came all the others. Then came that stigmatization that one was an evildoer. And that wasn't right in my opinion because we all tried our best, everything we could." (TYKL/spa/519: informant 43). In 1985 in Sähkösanoma (Permanto 1985: 1213), the director of the laboratory department Lauri Oksanen said that the new way of thinking about environmental issues in the power plant had spread. According to Oksanen, the residents' perspective was now considered more comprehensively: "Now there are other priorities than just making electricity and heat, and the imprints left behind by all that."

As a community, the Hanasaari A power plant workers felt a sense of unity, involving engineers, executives and workmen alike. They felt that the chief executive of the power plant was an essential part of the atmosphere of Hanasaari A (e.g. TYKL/spa/519: informants 1, 9, 19, 28, 43, 44). According to the workers I interviewed (e.g. TYKL/spa/519: informants $13,41,43)$. It was the top man who was in charge of the overall atmosphere, even in smaller sub-groups such as the different shifts in the control room.

Hanasaari A's workers also had shared problems that reflected the darker nuances of their industrial heritage. The worst health and social problems were caused by alcohol and later by asbestos. As late as in 1976, Sähkösanoma (11) wrote about alcohol as a collective problem. The article demanded instructions to action, education and information and criticised the power plant's official "hush agenda". Plenty of asbestos was used as insulation in the equipment used at Hanasaari $\mathrm{A}$ and 


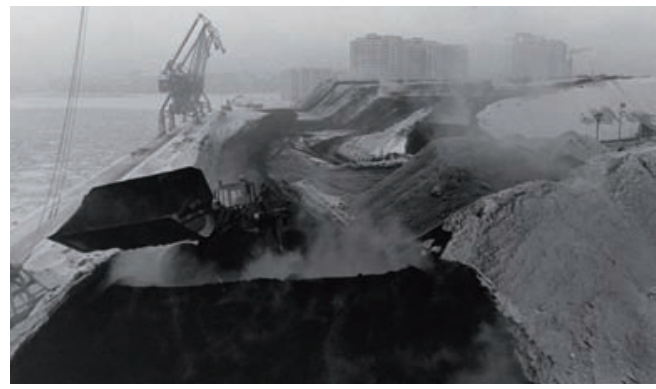

Fig. 6. The coal field in the winter of 1979. It looks almost magical, steaming because of the sub-zero temperatures. Photograph from the archives of Helsinki Energy.

equipment such as asbestos overalls, asbestos gloves and even asbestos pillows were also offered to mechanics in difficult working positions, while blue asbestos was sprayed without any protective outfits. When the knowledge about the dangers of asbestos increased, the company doctors examined all the Hanasaari A workers for the effects of being exposed to asbestos. Out of about a thousand patients examined, 150 were found to have some degree of asbestos-related diseases (e.g. TYKL/spa/ 519: informants $1,2,8,28,40,46)$.

\section{HANASAARI A AS A CULTURE FACTORY}

Helsinki Energy has a long tradition when it comes to co-operating with cultural opinionmakers. In the 1980s, the Suvilahti power plant served as a movie set as well as co-operating in theatre productions. It now serves as an exercise space for the employees of Helsinki Energy and is also in business use. In future, the plan is to alter Suvilahti for cultural and industrial art uses (Aalto 2006: 43-44).

It is notable that the many discourses considering Hanasaari A usually bring up aesthetical factors - the "ugliness" of the power plant.
This theme has its roots in the 1960s when the coal storage facilities were objects of public discussion. "Coalfields, beautiful or ugly?" was a subheading in an article that dealt with Polish coal in Sähkösanoma (2-3/1965: 7). The article recounts that the coal fields have been publicly criticised as being unaesthetic and unclean and from ruining the shoreline of the island. However, engineer Neuvo from the power plant saw also beauty in the coal fields: "If one looks closely at the coal piles for our power plant, they are really beautiful, there's nothing to criticise. A coalfield is not an ugly sight to behold; it is a beautiful black pile or a solid, smoothed area." (Sähkösanoma 2-3/ 1965: 7) (Fig. 6).

In 1993, the artists Ritva Harle, Hanna Vainio and Jukka Kuuranne planned and built a work of art entitled "Volcano" (Tulivuori in Finnish) using grass strips on the coal storage areas. Environment art was also on display from spring to autumn over the course of three summers (Aalto 2006: 45-46). Hanasaari A was surrounded by poplar trees; there are nearly 50 of them in the area and they already form a significant part of the landscape. There was also a larger landscape gardening scheme under preparation for the power plant at the end of 1990s, when Hanasaari power plant's director Hannu Kekkonen asked architect Sakari Tilanterä for a proposal for renewing the grey fibre-cement facade of Hanasaari A. Then came an art installation surrounding the coal storage, entitled "Against the light" (Vastavalo in Finnish) by Sakari Tilanterä, which was ready for display in summer 2004 . This installation contained 56 bright poles that form a hedge around the coal storage area (Fig. 7). The power plant got company from another light installation in winter 2005, when students of the Environmental Art Programme at the Uni- 


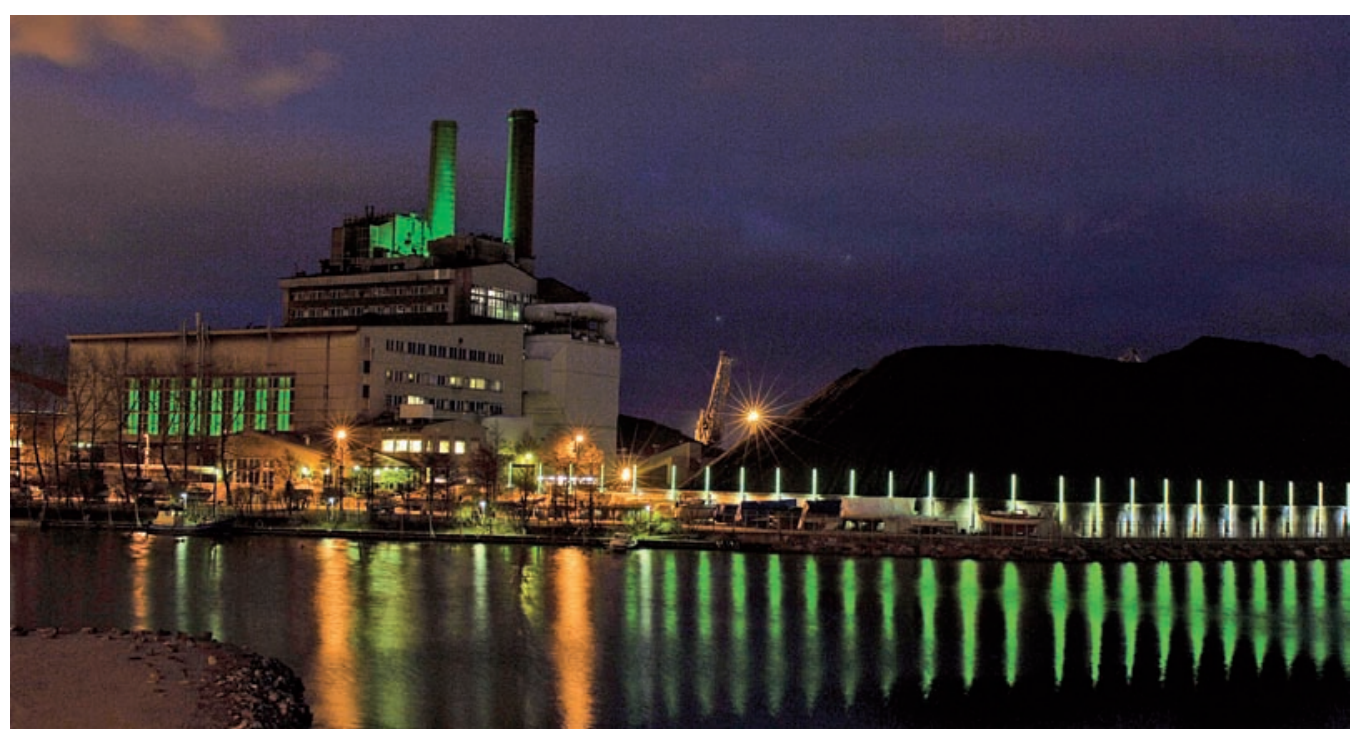

Fig. 7. The installation "Against the Light" (Vastavalo in Finnish) by architect Sakari Tilanterä in Hanasaari A. This work was inaugurated on 11.6.2004 for the 30th anniversary of Hanasaari A. According to Tilanterä (2004: 5), the principle behind the installation's design was to affect the cityscape and to enliven the coal warehouse in the eyes of its neighbours. The installation was planned so that it was best seen from Merihaka. Photograph from the archives of Helsinki Energy.

versity of Art and Design built the outcome of a Light and Space workshop. For three and a half months, Hanasaari A therefore glowed in different shades of green. These works of art aimed at landscaping the area and enliven the power plant and benefiting the inhabitants of Merihaka (Aalto 2006: 44-45).

Linking extraordinary activities such as environmental art projects and the heritage documentation project to the normal operation of a power plant have required active individuals in the management of Helsinki Energy. Hannu Kekkonen, the current director of the power plants, got enthusiastic about the "Against the Light" (Vastavalo in Finnish) installation based on his own experiments with lead lights (TYKL/spa/519/ informant: 11), and environmental director Martti Hyvönen is considered the father of the heritage documentation project (e.g.TYKL/spa/519: informants 11, 19, 43). With their contributions, Hanasaari A's workers experienced unique moments in the first years of this decade when the power plant had been removed from its use as a power plant.

"So then came Hollywood. There started to be this and that and they had to be helped with it all. Well, it started to be a full time job and we had to help them all the time. ... I've been in some movies, too. ... That's where it ended then, when it started to be a little scary, that if something happens there, that they hurt [themselves]. When they made them by night those [shoots] and everything and there 


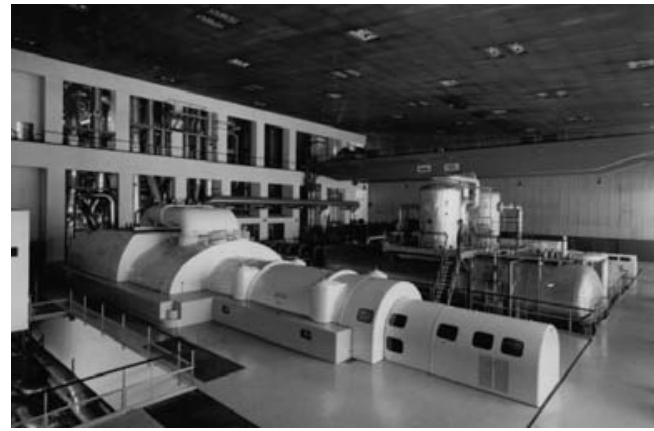

Fig. 8. Interesting design feature from the 1950s in the turbine hall of Hanasaari A. Photograph from the archives of Helsinki Energy.

was no one to keep an eye on them. We had to put flag lines and different kinds of barriers to the gaps in the railings," said one of the "house-elves" of Hanasaari A, looking back on working in the empty power plant (TYKL/ spa/519: informant 45). The jobs of the last people working in the power plant were to keep the property warm and ready to start if needed (e.g. TYKL/spa/519: informant 46). The cultural work and the interest and respect for the milieu and the work in Hanasaari A from the cultural workers raised respect for the power plant and its history even in the eyes of the power plant workers (TYKL/ spa/519: informant 8). It might also have had an effect reflected in their enthusiastic approach to the cultural heritage documentation project in 2007.

In 2002, photographer Markku Lähdesmäki took a series of photos in Hanasaari, photographing workers as they carried out their jobs. Hanasaari surprised the photographer: "I was impressed by the beautiful shapes found in the power plant: how metal sheets had been twisted into pipes. ... Hanasaari A is an ugly building outside, but the more I got to know my subject, the more beautiful it looked on the inside - and even outside." (Galkin 2002: 4). Lähdesmäki used humour in his photographs and his models were also the workers of Hanasaari A, true personalities who put the soul into these works of art (Galkin 2002: 4).

The romanticism of urban industrial environments and machinery in Hanasaari A have provided a rich source of inspiration for artists. Music videos and album covers have been shot here by The Rasmus, HIM and Apocalyptica, for example. TV series have been made in Hanasaari A, Formula One driver Nico Rosberg's sponsor launch event was held here and Aki Kaurismäki's movie "Lights in the Dusk" (Laitakaupungin valot in Finnish) was partly shot in the building (Aalto 2006: 47). The Film Industry has shot most of the Record Factory (Ennätystehdas in Finnish) entertainment programme in Hanasaari A, which provided a functional backdrop for a programme based on people's efforts to set new records: "Our lighting professionals, whose job is to make entertainment, but who have that artistic function too, they set those lights into the walls with broken hearts. ... I haven't met a practitioner of that profession, cameraman, director, producer, who wouldn't have fallen in love with that place immediately," declared the producer of Record Factory Osku Pajamäki. He regarded the power plant as an easy place to adapt to the needs of different cultural productions, comparing Hanasaari A's design idiom to that of the Flash Gordon comics (TYKL/spa/519: informant 24) (Fig.8.).

TV producer Osku Pajamäki is also a Helsinki city councillor for the FSDP party. He was a member of the city government when the decision to demolish Hanasaari A was taken in February 2006, in connection with the Kalasatama [Fiskhamnen in Finnish] master 
plan. At that point in time, according to Pajamäki, the reasons for demolishing the frail old building felt clear. There didn't seem to be much use for it and the area was ideal for residential buildings. However, Pajamäki's opinion changed after his visit to Hanasaari A (TYKL/spa/519: informant 24).

In the autumn of 2007 , the plan was to make a new installation of the pieces of Hanasaari A for the entrance to the energy maintenance area. The purpose was that students of the University of Arts and Design, as part of their "junk sculpture course", were to make a monument to commemorate Hanasaari A in their. A work of art entitled "Garden" (Puutarha in Finnish) was selected for production. The garden would have included elements from different themes, trees, a door and a cradle (e-mail message from Janne Virkkunen, the University of Arts and Design to environmental director of Helsinki Energy Martti Hyvönen 31.10.2007). This intriguing plan has not yet materialised, because the students had too little time to carry out the project.

\section{HANASAARI A AS AN OBJECT OF INDUSTRIAL HERITAGE}

Cultural heritage is both personal and a collective, shared tradition at one and the same time. Cultural heritage constitutes those things that are meant to be experienced by future generations, to be a part of their life and environment (Härö 2007: 8-10). The recognition of cultural heritage as a multi-dimensional phenomenon and the tendency to cherish the cultural heritage has generated considerable discussion in the period after the turn of the millennium, not only in the museological sphere but also in public arenas. However, industrial heritage has been a subject of rese- arch in Finland since the 1980s (for example Yliaho 1984 and 1986, Metsänkylä 1986) and The Society for Industrial Heritage was founded in 1985.

The final decision to demolish Hanasaari A was made by the Helsinki City Council in December 2006. The work began in winter 2007 and the documentation project was launched in summer 2007. As a museum professional working for Helsinki Energy in order to document industrial heritage, I got an opportunity to be a part of the intense and emotional process that the demolition of this power plant represented. In my project, I interviewed nearly 50 power plant workers, both former and current, including representatives of the Helsingin Sanomat newspaper, employees of the City Planning Department of Helsinki and representatives of the city council.

The collection, documentation and research of traditions have raised central issues in various academic fields since the 1980s. The oral history movement has affected research into tradition by emphasizing the relevance of the unique manner of informants' memories, their interpretations of their experiences and the past itself (e.g. Kalela 1984 and Kalela 1999, Thompson 1988). In Finland, the study of oral history is now a multidisciplinary field that sidesteps research into industrial heritage (e.g. Muistitiedon tutkimus. Metodologisia kysymyksiä 2006).

According to Taina Ukkonen (2000), it is not relevant to ponder the relation between reality and tradition from the perspective of oral history scholars. The tradition should be studied as interpretations of reality and the research questions should ponder what kind of things and occasions are considered worth telling and how they are remembered and studied. It is thus a matter of choice and interpreta- 


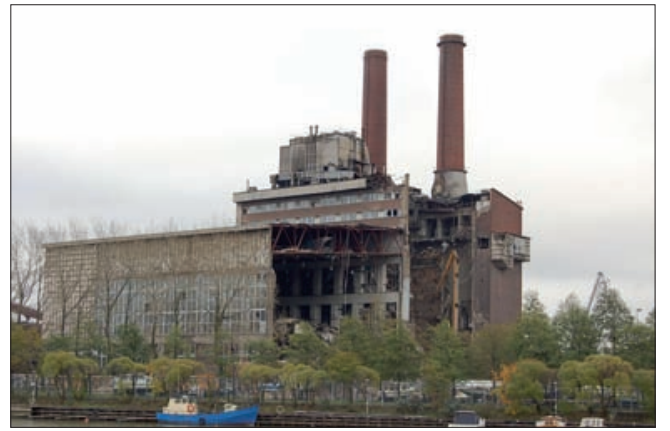

Fig. 9. In the demolition of Hanasaari $A$, a special technique was used (TYKL/spa/519: informant 38). In simple terms, the power plant was dug out from one side, so the building and the processes inside were not separated during the work.

Museum equipment has been removed at the point pictured here. During the demolition process, the façade facing the city was as far as possible preserved intact while the work began from the sea-facing side. The photograph shows the situation in October 2007. Photograph: Arja Jurasch, the archives of Helsinki Energy.

tion of the past, as well as of the way tradition is used as a source. These were the interpretation, the values and meanings of Hanasaari A I specifically attempted to find in the documentation project.

However, it is relevant to realise that a tradition documentation project is never fully researchers' project. It is also a collective effort, because the formation of historical knowledge demands commitment to a collective objective and en experience of meaningfulness from all the parties concerned (Ukkonen 2006: 182). Both current employees of Helsinki Energy and retired power plant workers were surprisingly willing to be interviewed, which I see as a sign of a mutual respect for gathering together the industrial heritage of the power plant. Only a few declined to take part in interviews and they appealed to modesty, sa- ying that the relevant factors must have came out already in other interviews.

Current employees of Helsinki Energy criticized demolishing Hanasaari A in such haste (e.g. TYKL/spa/519: informants 19, 41, 43), which took some motivation from the power plant staff in terms of actively collecting data related to its industrial heritage. Hanasaari power plants' director Hannu Kekkonen mentioned these schedules in an interview: "I was laughing to myself, that this was like in the invasion of Kannas [the Karelian Isthmus during the Continuation War, summer 1944], that it was a hasty retreat and we went fast. Others were coming and we fled rapidly. And so we managed it." (TYKL/spa/519: informant 11). Environmental director of Helsinki Energy Martti Hyvönen says about the beginning of the documentation project: "When they decided that it was to be demolished and they made oddly hasty plans about it, then I and a couple of others, who have been here, and also our managing director, thought that it [Hanasaari A] will not just go away secretly but this history has to be respected and this how many people have worked there. ... And actually I've thought myself that after ten or twenty years, when people miss it more, we wouldn't have to be ashamed for not keeping it." (TYKL/spa/519: informant 8). The demolition had to begin as scheduled, and this was considered the hardest part of the whole enterprise (TYKL/spa/519: informant 38) (Fig. 9).

On the whole, the visual documentation and interviews were seen as an excellent way to record the industrial heritage of Hanasaari A (e.g. TYKL/spa/519: informants 8, 19, 38, 43). For example, the process of demolishing the power plant is documented with still - pictures taken from the window of Hanasaari B 


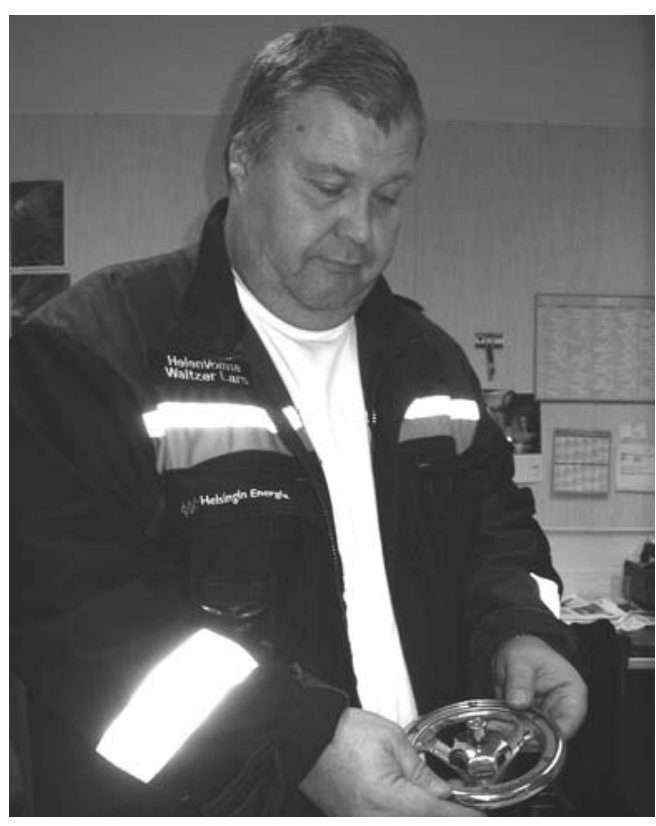

Fig. 10. Project engineer Lars Walzer, who worked actively in the industrial heritage documentation project, and an important object. After prolonged consideration, Walzer wanted to take as a keepsake the first valve used in starting the first machine of the generator. Each shift master at the power plant and supervisor of the turbine departments had used that particular valve to start the first machine. A special touch was essential: the valve could not be turned too fast or too slow, because of the vibration of the turbine. According to Walzer, this was typical for Hanasaari A - one had to know a lot of little tricks in order to use the machinery properly. Photograph: Maija Kärki, the archives of Helsinki Energy.

(TYKL/spa/519: informant 19). The collection of heritage in material form was transferred to various instances, to museums, and the University of Arts and Design but also inside the power plant's community from older to younger workers (TYKL/spa/519: informant 43) (Fig. 10). Some of the workers regarded the keeping of material culture important, alt- hough they did understand the limitations of storage space in the museums because of the large size of the equipment. Workers were pleased with the ideas and the collection of equipment by Helsinki City Museum, but they wondered about the passivity of other museums (TYKL/spa/519: informants 19, 20, 43).

What then is the industrial heritage in the case of Hanasaari A? Materially, it is recorded tapes, and their transcriptions, that contain interviews with the management of the power plant, engineers, laboratory staff, the users and maintenance men: boiler- and turbine men, the staff of the control room, electricians, water workers, and the workmen in the workshop and scaffolding men. In these interviews, the informants look back on their lives and work in the power plant; they describe their tasks and tell about leisure time, living in company apartments and things experienced after retirement. The interviews describe the final phases of Hanasaari A, its changing meaning in cultural production and finally the decision to demolish the power plant and the demolition process itself. The material heritage also contains photographs, videos and equipment; these elements of material heritage also contain the mental tradition left behind by Hanasaari A.

\section{Demolishing Hanasaari A}

Chief Intendant of the Unit for Architectural Heritage at the Department of Monuments and Sites, National Bureau of Antiquities, Mikko Härö (2007: 8-13) has formulated a statement about Hanasaari A in Museo (periodical of the Finnish Museum Association). Härö regards Hanasaari A as one part of an exceptionally valuable unit of three power plants, from which only the oldest, Suvilahti 
MAIJA KÄRKI

98

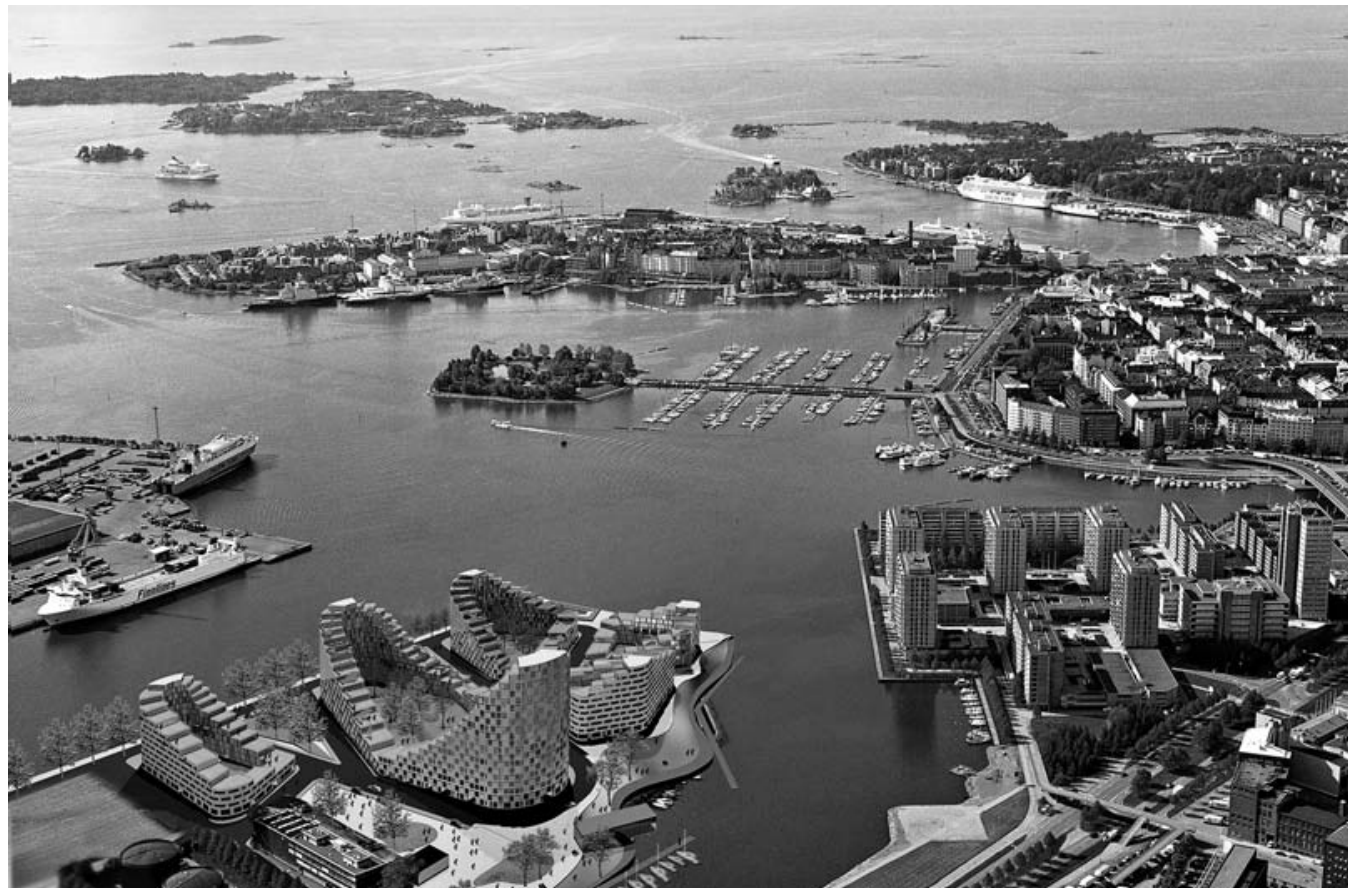

Fig. 11. Bird's-eye view of the terraced housing. The design competition looked for solutions that would pave the way to high-standard dwellings and recreational spaces in Hanasaari. The heights of the blocks ranged from one to over 20 floors and one block contains more than one thousand apartments. On the uppermost floors there are wide terraces and about 130 apartments (Hanasaaren asemakaavallinen ideakilpailu 3.11.2006-13.2.2007. Arvostelupöytäkirja). Illustration: ALA Architects Ltd.

has been preserved. "The conservation of $\mathrm{Ha}$ nasaari $\mathrm{A}$ as it is, with all its equipment and machinery, would have been unusually difficult although extraordinary museum work," Härö writes (2007: 11) and mentions examples of such activity around the world. For example, Battersea Power Station in London has been preserved and renovated as a consequence of pressure from inhabitants of the city. The Tate Modern is also an old phased-out power plant. The essential features of old power plants, such as the huge turbine halls and central location in the city area, have resulted in a range of renewed uses for such buildings, including as restaurants, hotels and museums (Rescue Hanasaari A -web site, Scadden 2001).

Harri Andersson (1993: 35-39) has studied the principles that define ways to assess the renewal usages of industrial buildings and areas, as opposed to demolishing them and building something new. Their meaning in the cityscape is connected to a subjectively defined area, a place that needs to be created, maintained and experienced. The feeling and recognizing of a place is considered to comprise of emotional bonds between a person and his/her every- 
day world (Andersson 1993: 36-37). Urban planning is closely connected to the meanings of the city's structure. Wide-scale renewal projects often concern phased-out factory and warehouse buildings and the areas around them, which go through a comprehensive "purification" process. The outcomes of these projects are often exclusive residential areas for the post-industrial society's growing middle class (Andersson 1993: 24, 37).

The workers of Hanasaari A had plenty of visions about new uses for the power plant. The informants often raised the alternative of museum use and other leisure activities such as restaurants and theatre activities (TYKL/ spa/519: informants $11,19,20,41,43)$. The Hanasaari power plant's director Kekkonen presented a post-modern idea: "In my soul, as I moved those ugly things away, I saw a lot of good ideas in it [Hanasaari A]. Eventually I ... wrote a long text, where I tried to share those ideas ... There were those electric filters, those I managed to [see] them already being a terrace. The moonlight illuminates the starry sky and then there are cafés ... Then a greenhouse on the roof, to sort of compensate for the electric filter. Then the turbine hall, which could be a shopping centre and a parking hall downstairs and then the boiler hall, with some apartments there. I mean, the fibre-cement wall doesn't have to be kept, but they could make walls from wooden fencing like at the McDonald's headquarters. I mean, it is sort of a pity, because no one cares to carry out that kind of architecture from the beginning. It forces people to be creative, when you're presented with a definite of conditions. A movie theatre and water purification and things like that, I wrote." (TYKL/spa/519: informant 11). The text ended being signed with a pseudonym for the Rescue Hanasaari A web site.
The history of the shore of Sörnäinen is industrial but the future of the district is apartments, offices and green areas, according to the visions of the City Planning Department of Helsinki (Aalto 2006: 57). The preservation and transformation of Hanasaari A, which is connected to the forthcoming Kalasatama project, for any other uses was considered unrealistic in the City Planning Department and the management of Helsinki TYKL/ spa/519: informant 35). In relation to the land use plans, preparations for an international idea competition were launched and the winner was the Amphibia project from the Harris-Kjisik architectural firm in Helsinki (Aalto 2006: 57). The district is planned to house 15,000 inhabitants and in 25 years there should be 6,000 new jobs (Aalto 2006: 57-58).

There was also a design competition for the residential area in the place of Hanasaari A , won by the Tropaion proposal from the architectural firm ALA Architects Ltd. (Huhtanen: Helsingin Sanomat 13.4.2007, see also Hanasaaren asemakaavallinen ideakilpailu 3.11. 2006-13.2.2007. Arvostelupöytäkirja.) (Fig.11. and 12.). The winning plan introduces a curved block that would change the entire façade of Helsinki from the sea. The residential blocks would resemble ships, so that the memory of the harbour would be carried over into the new residential area. (Hämäläinen: "Laivatalot" rantautuvat Hanasaaren kärkeen, Helsingin Uutiset 13.4.2007).

The decision to demolish Hanasaari A was not made easily and a conflict was born between the citizens and decision-makers. There was also tension between Helsinki Energy and the City Planning Department although they were both part of the same administration (e.g. TYKL/spa/519: informants 8, 11, 35). 
100 Industrial lots changed to urban waste land, which can be seen as a consequence of production conflicts and which led to the controversies about the use of city land (Andersson 1993: 39). For a long time, the Hanasaari A site was reserved as spare space for future needs and Hanasaari C (Pirvola 2007: 72). According to Pirvola (2007: 73-74), the city's reasons for demolishing Hanasaari A were mainly financial. The land beneath the pile of coal and the phased-out power plant was too valuable not to be used and the financial values surpassed any other value considerations. "It makes me want to spit; when I think of the statement made by city planner XX that we will now get rid of the history of poverty. ... This city doesn't want only to get rid of the history of poverty but also the history of work." (TYKL/spa/519: informant 24).

The conflicts about new uses for industrial areas can be administrative or social, and they are often connected with conflicts in preservation and renewed construction (Andersson 1993: 40-43). These conflicts also attract media attention. Journalist of Helsingin Sanomat Jarmo Huhtanen got interested in Hanasaari A in November 2006 and he made his interest public with three articles in the Helsingin Sanomat newspaper (23.11.2006, 25.2.2007 and 13.4.2007) and several blog texts (5.11.2006, 14.11.2006, 22.11.2006 and 5.12.2006). Huhtanen observed the endeavours of the activists but he did not at any point believe the city was willing to preserve the power plant (TYKL/ spa/519: informant 7).

"Here was a funny profane alliance between the old technology, engineering and industrybased men and the youngsters from the urban youth culture, who were partly in the same camp. That happens quite rarely. And nothing was said about people from the workplace or building that they have worked in would want to preserve it. On the contrary. That it is from them [the power plant community] a sincere pride for that place, quite terrific." (TYKL/ spa/519: informant 24). The question of the justification for the city space comes from social controversies. "On whose terms is the city being renewed?" is a question that connects power issues to the production of constructed environments (Andersson 1993: 43).

Osku Pajamäki voted against the party line in the city council when the decision of the demolition of Hanasaari A came into question. In an interview, he later commented: "But it doesn't make me frustrated that way, when really someone records this process and there are plenty of people who have that view [about Hanasaari A]. So that the comprehension of that [industrial heritage]. There's lot of it. ... I do slightly wonder about my own party in all these things, our Social Democratic party that should like somehow carry its [background] with pride. ... I mean this is industrial history heritage. As a working class exactly. It is truly like social climbing, if you don't understand those symbols." (TYKL/ spa/519: informant: 24).

To some spectators to the conflict as well as to activists, the decision to demolish Hanasaari A weighed heavily. Pajamäki continues: "Although XX didn't really ever fully comprehend it, when you saw that [the decision] was made based in completely wrong grounds and arguments, it was really heavy, that first lesson and many times the last [lesson] of politics, when you see that things, papers that they have relied on, and when you yourself know some thing ...These people made decisions based on nonsense. ... It is murderous for people. You can never explain it to them with anything and then how I've somehow accep- 


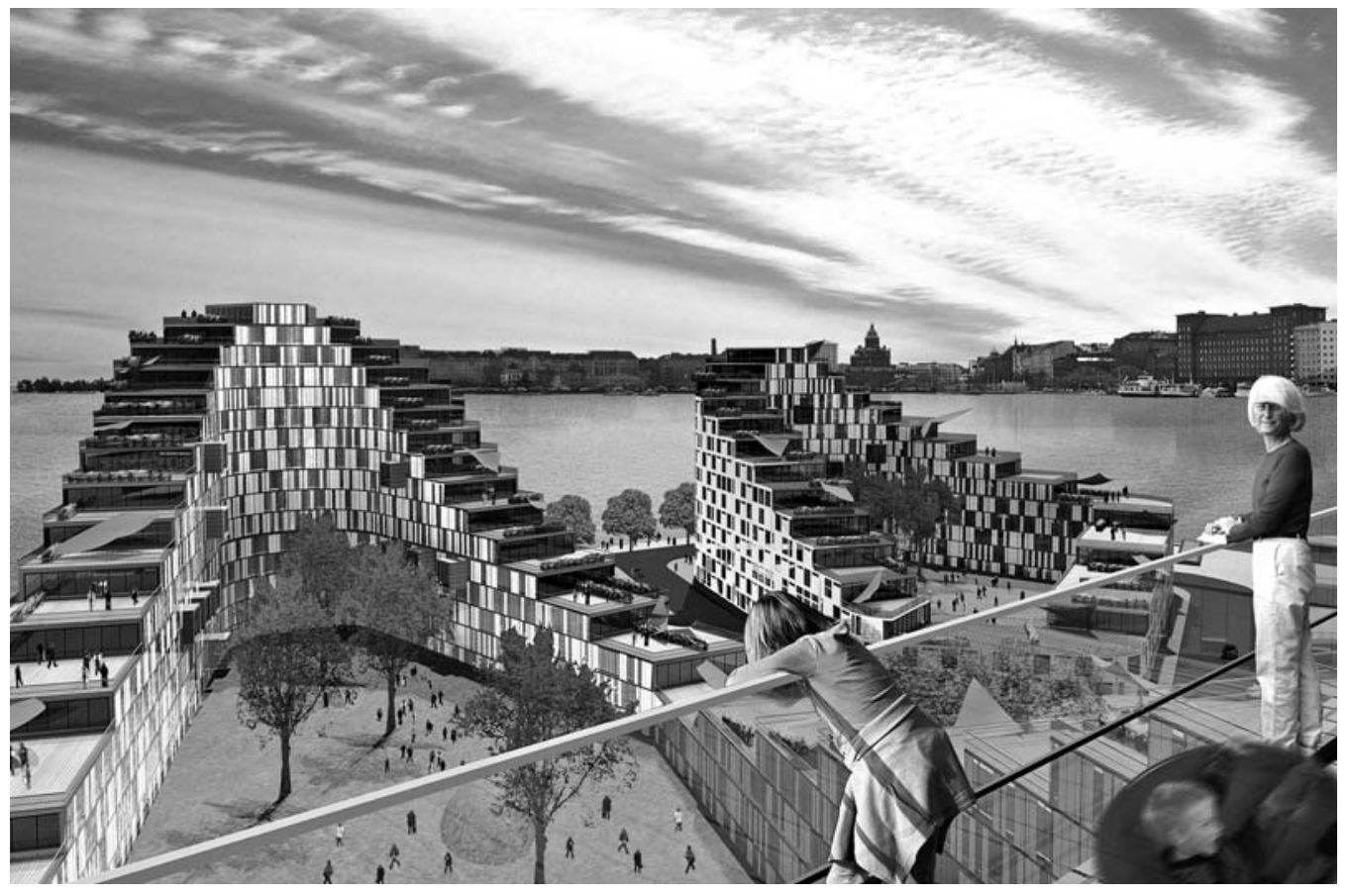

Fig. 12. The view into the sheltered inner courtyard. In his article (HS 13.4.2007), journalist Jarmo Hubtanen wondered why the illustrations do not show the Hanasaari B power plant or the forthcoming coal silos, which would change the character of the district considerably. Illustration: ALA Architects Ltd.

ted it and got used to it. It just is so." (TYKL/ spa/519: informant 24). Another informant formulates the situation thus: "From that process I got the impression that the politicians didn't have time nor interest to familiarize themselves with the matter, or use their own brains. [People] fed those ideas to them and they simply accepted that the situation was like that. No one stopped to think what the motives were and what facts were available. At least I would've hoped that it would have been properly investigated, even though the plant would have ended up demolished anyway." (TYKL/spa/519: informant 20).

Although the decision to demolish Hana- saari A had been made, Helsinki Energy immediately launched an inside inspection to identify the power plant's museal values. Maintenance engineer Kaj Luukko prepared a memo on the museal values of Hanasaari A and the collection work was carried out partly on this basis. The memo says that Hanasaari A is technically nearly in its original state; the equipment had not gone through any major modernizations or renewals. Even the automated equipment was authentic. It should be noted that museal values are not necessarily reduced by any changes. Instead the lifespan of an object and its chronological layers increase the museal value. Retired project engineer 


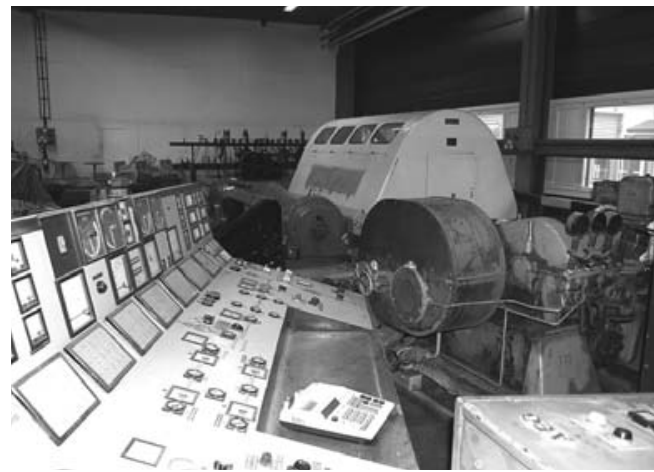

Fig. 13. Equipment from Hanasaari A transferred to a temporary warehouse in October 2007 so that it could subsequently be transferred for museum use. Photograph Arja Jurasch, the archives of Helsinki Energy.

Aarni Somerikko and Kaj Luukko wrote registers of the equipment and systems preserved from Hanasaari A. Somerikko's register contained objects emphasizing metering and controlling equipment, whereas Luukko's register particularly emphasized historical design.

The power plant equipment from each process was stored on the basis of these registers (Fig. 13). Representations of the boiler department, turbine department, district heating department, sea water refrigeration department, electrical automation, water purification and control mechanisms were thus preserved. The final site for preserving all these objects has not yet been found. Part of the equipment ended up in the Helsinki City Museum, part in the Museum of Technology. Part of the equipment was to have been used in projects run by the University of Arts and Culture. Part will probably end up in Hanasaari B to help commemorate the neighbouring power plant.

\section{CONCLUSION}

"The name of the island, which our stroller hardly knew, was Hanasaari. That name was subsequently to acquire completely different connotations and these meant the island was to remain in chronicles of public debate even when there was nothing of the island left visible." (Toivainen 1967: 7). These values are again after 40 years in a state of flux. Just as the rocky isle has nearly disappeared from our collective memory, the Hanasaari A power plant is being crushed to the ground to make way for a new residential area as well as for new values and meanings. However, the documentation project made it possible to preserve some parts of Hanasaari A's heritage, along with some of the values and meanings that were connected to it in its life cycle extending over half a decade.

The Hanasaari A power plant represented symbolical and identity values to the those who built and used it, to the whole community of the power plant. Hanasaari A also represented local values to many workers at the plant. These different layers of value were seen by the artists, who brought life to Hanasaari A in a new way. The bureaucrats of the city saw the financial values of Hanasaari A as defects of productivity. They were blind to the cultural values of Hanasaari A as increasing the object's market value, although in other countries these values were considered worth saving.

Maintenance master Reino Pankkonen, who worked in Hanasaari A's turbine department during the 1990s, agrees: “That's why this was such a good department. It was like driving a Mercedes - it represented the peak of quality in its field." (Jarmo Huhtanen HS 25.2.2007)

I am grateful for the help provided by the enthusiastic and professional staff of Helsinki Energy, and in particular environmental di- 
rector Martti Hyvönen, maintenance engineer Kaj Luukko, project engineer Lars Walzer, information specialist Heli Eloranta and librarian Arja Jurasch. I also thank all those who I interviewed and who provided other information.

\section{BIBLIOGRAPHY AND SOURCES}

\section{Unpublished sources}

Pirvola, Ilkka: Raamit vai monumentti? Tutkielma voimalaitosten arkkitehtuurisesta kehityksestä suomalaisessa kaupunkiympäristössä. Turun yliopiston taidehistorian pro gradu -tutkielma (pro gradu thesis in Art History at the University of Turku) 2007.

The archives of Helsinki Energy:

Arponen, Osmo. Juhlapuhe Hanasaari B:n 30-vuotistilaisuudessa (Osmo Arponen's main speech for the 30th anniversary of Hanasaari B) 11.6. 2004.

Luukko, Kaj: Muistio Hanasaari A:n museoarvoista (A memo about the museal values of Hanasaari A) 28.6.2007.

Sähköpostiviesti Taideteollisen korkeakoulun Janne Virkkuselta ympäristöjohtaja Martti Hyvöselle (e-mail message from Janne Virkkunen, the University of Arts and Design to Martti Hyvönen, environmental director of Helsinki Energy) 31.10.2007.

All the material of the documentation project has been preserved in the archives of Helsinki Energy.

The archives of the Turku University School of Cultural Research:

(Unbound primary data)

Interviews on CD-ROMs): TYKL/spa/517 ja TYKL/spa/518.

Haastattelulitteraatiot (Interview transcripts): TYKL/spa/519: informantit 1-47.

\section{Internet sources}

Helsingin kaupunginvaltuutun Osku Pajamäen blogi-kirjoitukset (Blog texts by Osku Pajamäki, city councillor of Helsinki) 5.11.2006 ja 4.12.2006: http://www.osku.net/ 13.1.2008.

Helsingin Sanomien toimittajan Jarmo Huhtasen blogi-kirjoitukset (Blog texts by Jarmo Huhtanen, journalist at Helsingin Sanomat) 5.11.2006, 14.11.2006, 22.11.2006, 5.12. 2006: http://www.blogit.hs.fi/helsinki/ 13.1. 2008.

Rescue Hanasaari A -web site 13.1.2008: http://hanasaari.hopto.org/

\section{BIBLIOGRAPHY}

Aalto, Laura. Sörnäisten Energiahuoltoalue. Edita Prima Oy: Helsinki 2006.

Andersson, Harri. Rakennettu ympäristö. - kaupunki rakentamisen modernina projektina. Turun yliopiston täydennyskoulutuskeskuksen julkaisuja A:10. Painosalama Oy: Turku 1993.

Galkin, Marina. Taiteilija ikuisti Hanasaari A:n ainutlaatuisen tunnelman. Teollisuuselementit ja ihminen kohtaavat Voimala-näyttelyssä. Impulssi 12/2002: 4 .

Hanasaaren asemakaavallinen ideakilpailu 3.11.2006-13.2.2007. Arvostelupöytäkirja. Helsingin kaupunkisuunnitteluviraston julkaisuja 2007:7. Helsinki.

Huhtanen, Jarmo. Hanasaarelle koittaa kolmas elämä. Koneita ja laitteita irrotetaan museoihin ja ympäristötaiteeksi. Helsingin Sanomat 25.2.2007.

Huhtanen, Jarmo. Hanasaaren A -voimalan purku nosti puolustajat vastarintaan. Helsingin Sanomat 23.11.2006.

Huhtanen, Jarmo. Hanasaaren ideakilpailun voittaja esittää kaarevia suurkortteleita. Hanasaaren kärkeen suunniteltujen asuntojen hintoja ei tiedetä. Helsingin Sanomat 13.4.2007. 
Hämäläinen, Jukka. "Laivatalot" rantautuvat Hanasaaren kärkeen. Helsingin Uutiset 13.4.2007.

Härö, Mikko. Perinteiden valtatiellä. Museo 2/2007: 8-13.

Isompi huolto tehdään joka 8 . vuosi. Hanasaaressa revisoidaan turbiinia. Impulssi 9/2004: 4-5.

Kalela, Jorma. Muistitietotutkimus ja historialiike. Kotiseutu 1/1984.

Kalela, Jorma. The Challenge of Oral History - the Need to Rethink Source Criticism. Ed. Ollila, Anne: Historical Perspectives on Memory. Studia Historica 61. Helsinki: 1999.

Metsänkylä, Antti. Metallityön tallennus. Museoviraston Työväenkulttuuriprojektin julkaisu 4. Valtion painatuskeskus: Helsinki 1986.

Muistitietotutkimus. Metodologisia kysymyksiä. Toim. Fingerroos, Outi, Haanpää, Riina, Heimo, Anne \& Peltonen, Ulla-Maija. Tietolipas 214. Hakapaino Oy: Helsinki 2006.

Permanto, Eeva-Maija. Lauri Oksanen: ”Ajattelutapa avartunut ympäristöasioissa”. Sähkösanoma 3/1985: 12-13.

Satama ja liikenne Hanasaaren riesat. Sähkösanoma 3/1981: 14-16.

Scadden, Richard A. Adaptive Re-use of Obsolete Power Plants. Technical Paper 1/2001.

Teollisuustilan uuskäyttö Turun kaupunkikeskustassa. Toim. Harri Andersson. Painatuskeskus: Turku 1990.

Terveysviraston valvontaosasto: Kun Hanasaari A vielä saataisiin kiinni. Sähkösanoma 1/1989: 20-21.

Thompson, Paul. The Voice of the Past. Oral History. Oxford University Press: Oxford 1988.

Tilateos vihittiin käyttöön - hiilivarasto osana kaupunkikuvaa. Hanasaaressa vietettiin 30-vuotisjuhlaa. Impulssi 6/2004: 4-5.

Toivainen, Eino. Kallioisen saaren tarina. Eli kuinka tehtiin Hanasaari. Sähkösanoma 1/1967: 7-9.

Turpeinen, Oiva. Energiaa pääkaupunkiseudulle. Sähkölaitostoimintaa Helsingissä 1884-1984. Weilin + Göös: Espoo 1984.
Ukkonen, Taina. Muistitieto tutkimuksen kohteena ja aineistona. Elore 2/2000.

Ukkonen, Taina. Yhteistyö, vuorovaikutus ja narratiivisuus muistitietotutkimuksessa. Toim. Fingerroos, Outi, Haanpää, Riina, Heimo, Anne \& Peltonen, Ulla-Maija: Muistitietotutkimus. Metodologisia kysymyksiä. Tietolipas 214. Hakapaino Oy: Helsinki 2006.

Yliaho, Timo. Tehtaalainen lounaisessa Hämeessä. Jokioisten naulatehtaan työntekijän muotokuva n. 1900-1940. Museoviraston Työväenkulttuuriprojektin julkaisu 3. Valtion painatuskeskus: Helsinki 1984.

Yliaho, Timo. Muuttuva työ. Museoviraston Työväenkulttuuriprojektin julkaisu 5. Tampereen kirjapaino Oy: Tampere 1986.

* Maija Kärki MA works in the Department of Museology, School of Cultural Studies at the University of Turku and in the Archives of the Turku University School of Cultural Research. She also teaches museology part-time in the School of Cultural Production and Landscape Studies.

Address: School of Cultural Research Department of Museology FI-20014 University of Turku E-mail:maikar@utu.fi 